\title{
Italy: The Principle of Solidarity as a Principle of Equality
}

\author{
Erika Arban
}

As an aspirational principle and all-encompassing concept, solidarity infuses more or less extensively - several federal and federal-like systems as a concept that tends to promote equality, social rights, well-being, and friendship among and between the various players of a compound polity, even when it is not clearly spelled out in the articled parts of a constitutional text. Italy represents a clear example in this sense: in fact, solidarity is firmly entrenched in article 2 of the Constitution among the fundamental principles of the Republic, but it also infuses several other constitutional provisions, thus occupying a prominent role in the constitutional architecture of the state. In particular, solidarity deeply informs the relationship between the central state and regional governments, uniquely shaping Italian regionalism.

The purpose of this chapter is to chart the meaning and scope of solidarity in the Italian context in all its various understandings, but with particular attention to its relationship with regionalism. This chapter is divided in three parts. Section 1 sets the framework for the discussion, illustrating why Italy is a diverse and asymmetrical regional state where its constituent units (e.g. regions) enjoy mild forms of autonomy; section 2 describes solidarity and equality as aspirational values that deeply inform the socio-economic and political relationships among and between individuals and public institutions in Italy, while section 3 focuses on solidarity in the specific context of Italian regionalism, particularly after the constitutional reform of 2001 . In the conclusion, I argue that the principle of solidarity as entrenched in the Italian Constitution can be construed as an aspirational value fostering equality and unity in a rather diverse country. However, despite the noble intentions of this principle, its constitutional entrenchment has not fully succeeded in

1 This research was fully funded by the Australian Government through the Australian Research Council (ARC) Laureate Program 'Balancing Diversity and Social Cohesion in Democratic Constitutions'. 
preventing the consolidation of inequalities that might jeopardise equality in a state that has been historically characterised by deep socio-economic and political asymmetries: a return to the very meaning of solidarity should thus be encouraged.

In terms of methodology, the chapter will offer an extensive textual/analytical analysis of solidarity as embedded in the Italian Constitution, by also taking into account the readings of this principle offered by the Italian Constitutional Court (ItCC), ${ }^{2}$ considering that judges have the task of identifying, among other things, the values of the constitution. The goal of this chapter is not to be prescriptive or normative, nor to use a single case study to make general claims: as noted, its less ambitious purpose is to offer an analytical and descriptive account of solidarity as a principle of equality to better understand its value and meaning in Italy, also considering the challenging times and tensions that the country is facing at the time we are writing. Finally, while the chapter shows the interconnections between the twin principles of solidarity and equality, it extensively elaborates on the intellectual meaning of the former, without expounding the various understandings of the latter, whose meaning is thus implied.

\section{Autonomy and Diversity in Italy}

\subsection{De Facto Asymmetries}

Italy is a profoundly diverse country both de facto and de iure. From a factual standpoint, Italy has been traditionally characterised by a deep natural, historical, cultural, socio-economic, and linguistic fragmentation. Its natural diversity is reflected in the significant physical, geographical and climatic differences crossing the peninsula from the Alps to the Mediterranean, but Italy has also been historically characterised by other forms of asymmetries. As Eva explains, over the last 2800 years, Italy has had only a few centuries of unified history, mostly under the Roman Republic and Empire (from approximately 89

2 I ran a keyword search on the website of the ItCC (http://www.cortecostituzionale.it/actionPronuncia.do) using the term solidarietà and covering the 2002 to 2017 period: this specific timeframe is justified as I wanted to specifically take into consideration the reading of solidarity in relation to regionalism after the constitutional reform of 2001, considering the debate on federalism and solidarity that animated the political and constitutional discourse at the time. This keyword search returned about 379 results: however, only a smaller number of decisions were studied in preparation for this chapter, since a cursory reading of the decisions showed that in most cases solidarity was used in other contexts or mentioned in the text but the ItCC did not provide any clarification in this regard. 
в.C. to the fall of the Empire in 476 A.D.) and the period since unification (18611870). ${ }^{3}$ In the aftermath of the Congress of Vienna of 1815 , the Italian peninsula was still divided into eight different states: the Kingdom of Piemonte and Sardegna (under the rule of the House of Savoy); Lombardo-Veneto (a province of the Austrian Empire); the Dukedom of Modena and Reggio Emilia (under the rule of Frances IV); the Dukedom of Parma and Piacenza (administered by Mary Louise - daughter of the Austrian Emperor and Napoleon's widow); the Grand-Duchy of Toscana (governed by Leopold II of Lorraine - nephew of the Austrian Emperor); the Princedom of Lucca (governed by the Bourbons); the Papal State (which included part of Emilia, the Romagna, Marche, Umbria, and Lazio); and finally, the Kingdom of the Two Sicilies (under the Bourbons' rule, who were also linked to Austria). The fact that Italy was such a compound of non-homogeneous political structures (e.g. dukedoms, absolute monarchies, and theocracies - each of them with its own laws and institutional apparatus) had as a direct consequence the presence of substantial political and socioeconomic differences among the various geographical areas: in this scenario, Northern territories such as Piemonte, Lombardia and Veneto have historically been amongst the most economically developed areas. Italy's diversity is also reflected in the linguistic richness of the country, with hundreds of different dialects spoken across the peninsula, ${ }^{4}$ and linguistic minority groups living in specific parts of the territory. All these asymmetries have inevitably impacted and shaped the way the country functions and operates even today.

\subsection{De Iure Asymmetries}

But Italy is also de iure asymmetrical: mindful of the diverse fabric of the state, the Italian Constitution implemented in 1948 did not create a federal state, but

3 Fabrizio Eva, "Deconstructing Italy: (Northern) Italians and their new perception of territoriality," GeoJournal 48, no. 2 (1999): 102.

4 Eva also explains how, at the time of unification, "less than $3 \%$ of Italians spoke the Tuscan dialect - the basis of modern Italian - and many noble families preferred French as their main language. By 1955 still only some $30 \%$ of the population spoke Italian habitually or often. And even in 1987, $28 \%$ of Italians still used some dialect as their everyday language, although with an acceptable level of proficiency in Italian': Eva, "Deconstructing Italy," 102. Maiden points out that what is known as Italian was just one of the many dialects spoken in Italy (a Florentine variety of the Tuscan dialect). Therefore, Italian dialects are not variants of Italian, but of Latin, the latter thus being the 'mother' of all dialects spoken in the peninsula, including Italian. And because the 'common ancestor' is old, enormous differences exist between the various dialects (the greater the geographic distance, the greater the difference): Martin Maiden, "The Definition of Multilingualism in Historical Perspective," in Multilingualism in Italy, Past and Present, eds. Anna Laura Lepschy and Arturo Tosi (Oxford: European Humanities Research Centre of the University of Oxford, 2002), 32. 
nonetheless committed itself to the promotion of local self-government and to the broadest administrative decentralisation of services. In this regard, article 5 Const. postulates that

The Republic is one and indivisible. It recognises and promotes local autonomies and implements the fullest measure of administrative decentralisation in those services which depend on the State. The Republic adapts the principles and methods of its legislation to the requirements of autonomy and decentralisation.

Most importantly, the Constitution divides the territory into twenty regions, ${ }^{5}$ five of them vested with special status: Friuli Venezia Giulia, Sardegna, Sicilia, Trentino-Alto Adige and Valle d'Aosta. ${ }^{6}$ The rationale for this special status is a combination of geographical, linguistic and autonomist reasons: all five regions were very peripheral and thus disadvantaged at the time of their creation (with Sicilia and Sardegna being major islands), all of them were (and to a certain extent still are) characterised by the presence of more or less active movements fostering more autonomy and even independence, and the three regions in the North also present linguistic minorities in the territory. ${ }^{7}$ The special or autonomous status basically means that these five regions enjoy special forms and conditions of autonomy, implying more extensive - and thus asymmetric - powers than ordinary regions, especially in fiscal matters. ${ }^{8}$

The constitutional model created in 1948 was significantly revised in 2001 with the amendment of Title $\mathrm{v}$ of the Constitution (pertaining to the relationships between central and peripheral governments): among other things, this constitutional reform strengthened the legislative and administrative powers of ordinary regions, while leaving the powers of autonomous regions substantially untouched. This reform was the culminating point of a political mobilisation which began in the late 1980s, particularly in the North, where the wealthier and more industrialised regions sought to acquire more financial or fiscal autonomy, through increased decentralisation and even federalism: in other words, they sought to acquire more powers over the economy, infrastructure

5 See article 131 Const.

6 See article 116(1) Const. As further specified by article 116(2) Const., in Trentino-Alto Adige the two provinces of Trento and Bolzano also enjoy autonomous status.

7 French speaking minorities are present in Valle d'Aosta, German minorities exist in TrentinoAlto Adige, while Slovenian minorities live in Friuli Venezia Giulia.

8 According to article 116(1) Const. these five regions enjoy 'special forms and conditions of autonomy pursuant to the special charters adopted by constitutional law'. 
and other services so as not to depend on decisions coming from the central government, perceived as distant from the needs of these territories. ${ }^{9}$

In addition to confirming the binary division between autonomous and ordinary regions, the 2001 reform introduced another element of de iure asymmetry in article 116(3) Const., which now allows ordinary regions to negotiate, with the central government, particular forms and conditions of autonomy in specific subject matters. ${ }^{10}$ This provision has been dubbed 'differential regionalism'11 or 'regionalism having a variable geometry'12 or even 'asymmetric federalism.'13 I will revert to this provision later in the chapter.

Although (asymmetrically) decentralised, Italy is not a federal state in classical terms. Yet, at the time of the constitutional reform of 2001 there

9 It is not the goal of this chapter to retrace the history of the Italian decentralisation process and the facts, issues and political actors involved, as an abundant literature already exists on the topic. While not claiming to be exhaustive, the following is a short bibliography on the subject: Ugo Amoretti, "A new look at federalism: Italy decentralizes," Journal of Democracy 13, no. 2 (April 2002): 126; Gianfranco Baldini and Brunetta Baldi, "Decentralization in Italy and the Troubles of Federalization," Regional and Federal Studies 24, no. 1 (2014): 87; Beniamino Caravita, "Italy: Between the Hybrid State and Europe's Federalizing Process," in Routledge Handbook of Regionalism and Federalism, eds. John Loughlin, John Kinkaid and Wilfried Swenden (London and New York: Routledge, 2013), 287; Gian Franco Cartei and Vincenzo Ferraro, "Reform of the Fifth Title of the Italian Constitution: A First Step Towards a Federal System?," European Public Law 8, no. 4 (2002): 445; Louis Del Duca and Patrick Del Duca, "An Italian Federalism? The State, its Institutions and National Culture as Rule of Law Guarantor," American Journal of Comparative Law 54, no. 4 (Fall 2006): 799; Sergio Fabbrini and Marco Brunazzo, "Federalizing Italy: The Convergent Effects of Europeanization and Domestic Mobilization," Regional and Federal Studies 13, no. 1 (Spring 2003): 100; Tania Groppi and Nicoletta Scattone, "Italy:The Subsidiarity Principle," International Journal of Constitutional Law 4, no. 1 (January 2006): 131; Martino Mazzoleni, "The Italian Regionalization: A Story of Partisan Logics," Modern Italy 14, no. 2 (May 2009): 135; Cesare Pinelli, "The 1948 Italian Constitution and the 2006 Referendum: Food for Thought," European Constitutional Law Review 2, no. 3 (October 2006): 329.

10 Article 116(3) Const. lists the areas where enhanced autonomy can be negotiated: all matters of shared jurisdiction between the state and the regions, as specified by article $117(3)$; specific subject matters normally falling within the exclusive legislative jurisdiction of the central state, such as: organisational requirements of the justice of the peace (article $117(2)(\mathrm{l}))$; general norms on education (article $117(2)(\mathrm{n})$ ); and protection of the environment, eco-system, and cultural heritage (article $117(2)(\mathrm{s}))$.

11 Carlo Dapelo, "The Trends towards Federalism in Italy," St. Thomas Law Review 15, no. 2 (Winter 2002): 346 .

12 Paolo Caretti and Giovanni Tarli Barbieri, Diritto regionale (Torino: Giappichelli, 2012), 34.

13 Augusto Barbera, "Da un federalismo 'insincero' ad un regionalismo 'preso sul serio'? Una riflessione sull'esperienza regionale," Forum di Quaderni Costituzionali (October 2012): 15, http://www.forumcostituzionale.it/wordpress/images/stories/pdf/documenti_ forum/paper/o34O_barbera.pdf. 
was a widespread belief that this amendment represented the first step of a more drastic federalisation that would be completed in the years to come. ${ }^{14}$ However, this transformation has not yet taken place; federalism debates have lost momentum and, at the time we are writing, further federal amendments have basically disappeared from the agenda of all political parties, leaving only academics to engage in debates on the nature and status of Italian regionalism.

\subsection{Federalism and Solidarity in Italy}

The 1948 Constitution can be regarded as the product of a compromise between unitary and decentralising forces: in fact, the Italian state model is usually identified as an example of regional state, although nowhere in the Italian Constitution it is so indicated. While it may be difficult to precisely distinguish regional from federal states, the former are commonly labelled as quasi-federal since they present some federal traits without amounting to pure federations, and centralising forces are prevalent. For example, in our specific case study, the Italian Constitution entrenches a division of legislative powers between central and regional governments (this being a classic federal element), but it lacks many other important federal traits such as a federal Senate or a direct regional involvement in constitutional amendments.

As indicated above, a federal reform in Italy was discussed, initiated in 2001, but never completed. There are clear reasons suggesting why a complete reform in federal terms has not yet occurred. In fact, among other things, a widespread belief exists that a fully-fledged federal reform would irreparably compromise the unity of the state and the solidarity-based relationships that inform the Italian constitutional architecture, considering the prominent position that solidarity occupies among the fundamental principles of the Republic. In other words, federalism and solidarity are seen as hostile and competing values, in view of the risk that a federal solution would divide, rather than unite, the various territories of the country, thus compromising the idea of territorial solidarity among regions. ${ }^{15}$ Consequently, a fully-fledged federal state would

14 Ex multis, see Cartei and Ferraro, "Reform of the Fifth Title of the Italian Constitution," 445; Siegfried Wiessner, "The Movement Toward Federalism in Italy: A Policy-Oriented Perspective," St. Thomas Law Review 15, no. 2 (Winter 2002): 301; Del Duca and Del Duca, "An Italian Federalism?," 799, who talk about a 'nascent federalism combining Regionalization and Supranationalism'.

15 Andrea Patroni Griffi, "Federalismo, Mezzogiorno e sviluppo solidale," Forum di Quaderni Costituzionali: 3, http://www.forumcostituzionale.it/wordpress/images/stories/pdf/documenti_forum/paper/o247_patroni_griffi.pdf. 
deepen, rather than limit, the socio-economic inequalities among the twenty regions.

This tension between solidarity and federalism can be partially explained by the fact that the constitutional reform of 2001 was the result of years of intense political debate carried out under the aegis of federalism and initially led by the Northern League (LN), a political party rooted in the wealthier regions of the North that achieved electoral success and national visibility by critically questioning established behaviours of the elite class (e.g. excessive state spending, poor performance of public services, waste, corruption). The LN voiced the discontent of Northern Italy over the political attitude of the central government, which seemed to neglect the interests and needs of the most industrialised, fast-paced, and richer areas of the country to the advantage of the South. However, because these requests for increased autonomy were made by a political party firmly rooted in the richest area of the country, and thus embedded in the economic disparity existing between the wealthier North and the poorer South, one of the strongest censures made to the LN was that its federalism program merely aimed at furthering the economic and financial greed and selfishness of certain regions, while overlooking the needs of the poorer areas of the country. In other words, that part of the country that was seeking federal solutions was believed to want more powers without obligations towards the rest of the country (specifically, the South): for this reason, federalism was ostracised because of the conviction that it would discourage solidarity among the various areas of the territory. ${ }^{16}$ Consequently, while solidarity is a fundamental constitutional principle that significantly informs the constitutional framework of the state, a discussion on solidarity would not be complete without reference to regional autonomy and issues of socio-economic inequality, as will be better illustrated in section 3 .

\section{The Principle of Solidarity as an Aspirational Principle}

\subsection{Aspirational Principles in General}

Constitutions are usually intended to endure several generations and are commonly seen as the place to design the institutional architecture of a state. Building upon Stone and Arcioni, this chapter shares the view that constitutions are not only meant to last for a long time and to outline the main features

16 André Lecours and Erika Arban, "Why Federalism Does Not Always Take Shape: the Cases of Italy and Nepal," Regional and Federal Studies 25, no. 2 (2015): 187. 
of the polity in question, but they can also be construed as the repositories of shared values, as they often contain fundamental principles to which citizens aspire. ${ }^{17}$ In this regard, solidarity can be considered a shared value for citizens, as being a principle that helps define their identity (solidarity in its private understanding), the functioning of the state (solidarity in its public understanding), as well as other fundamental values (e.g. the preservation of human life, the protection of human dignity, rights provisions and social goals): this is particularly true in the case of post-conflict constitutions or constitutions that have emerged out of dictatorship, as was the case with many constitutions enacted after WWII. ${ }^{18}$ For this reason, the aspirational value of solidarity infuses several federal and quasi-federal systems as a principle that fosters equality, social rights, well-being, and friendship among and between the various actors - public and private - of a polity; and this is true even when it is not expressly spelled out in the constitution. ${ }^{19}$

Aspirational concepts such as solidarity thus help to define the overall ideals to which a given legal system ultimately strives for; but aspirational concepts risk remaining empty paradigms if not matched by some concrete mechanism that breathes life into them. It is thus important to understand the real meaning of solidarity to grasp how it can be construed as a principle of equality, both in general terms and in the specific case of Italy. When entrenched in a constitution, solidarity becomes aspirational in the sense that it directs certain policies to foster equality and eliminate obstacles; it also directs state policies to address certain issues based on equality.

\subsection{The Different Meanings of Legal Solidarity}

It is not the purpose of this chapter to thoroughly retrace the meaning of the solidarity principle as a philosophical concept, as an abundant literature already exists on the subject. ${ }^{20}$ As I have extensively explained

17 Elisa Arcioni and Adrienne Stone, "The Small Brown Bird: Values and Aspirations in the Australian Constitution," International Journal of Constitutional Law 14, no. 1 (January 2016): 1 and 4 .

18 Arcioni and Stone, "The Small Brown Bird," 2-3.

19 Erika Arban, "Exploring the Principle of (Federal) Solidarity," Review of Constitutional Studies 22, no. 2 (September 2017): 242.

$20 \quad$ Ex multis, see Arban, "Federal solidarity," 243; Lorenza Carlassare, "Solidarietà: un progetto politico," Costituzionalismo.it, no. 1 (May 2016): 45, http://www.costituzionalismo. it/download/Costituzionalismo_2016o1_559.pdf; Charles D. Gonthier, "Liberty, Equality, Fraternity: the Forgotten Leg of the Trilogy, or Fraternity: the Unspoken Third Pillar of Democracy," Mc Gill Law Journal 45, no. 3 (June 2000): 567; Juliane Ottmann, "The Concept of Solidarity in National and European Law: The Welfare State and the European Social Model," Vienna Journal on International Constitutional Law 2, no. 1 (January 2008): 36; 
elsewhere ${ }^{21}$ however, there is a conceptual distinction between moral and legal solidarity: in fact, while the former can be understood as a voluntary charitable act premised on mutual assistance or philanthropy, ${ }^{22}$ legal solidarity shall be understood as an 'obligatory act based on legal rights and duties' although some sentiments of mutual assistance might always come into play. ${ }^{23}$

Another important classification that should be made is that legal solidarity can acquire different meanings depending on whether it is entrenched in international or domestic law, in private or public law, or in federal theory. ${ }^{24}$ In private law, solidarity is linked to the concept of obligatio in solidum of Roman origins or, in the words of Black's law dictionary, ' $[t]$ he state of being jointly and severally liable (as for a debt)'.25 Solidarity in international law can be traced back to the French term fraternité which, along with liberté and égalité, was one of the three linchpins animating the French Revolution, later passed on to the French Constitution and, from there, to the Universal Declaration of Human Rights. ${ }^{26}$ According to some scholars, solidarity can in fact be understood as the legalisation or juridicalisation of the term fraternité. ${ }^{27}$

Within the ambit of public law, the spirit of solidarity can find expression in at least three different ways: the first relates to socio-economic rights and, more generally, welfare provisions, such as programs providing for health and social services. ${ }^{28}$ Second, solidarity can permeate provisions dealing with drastic emergencies such as terrorist attacks or natural disasters, usually binding actors at the local, national and even international levels. ${ }^{29}$ Third, solidarity in its public law understanding may refer to the general responsibility of the individual towards the community at large: in this sense, political solidarity commonly includes duties performed by subjects such as voting, homeland

Vincenzo Tondi delle Mura, "La solidarietà tra etica ed estetica, Tracce per una ricerca," Rivista dell'Associatione Italiana dei Costitutionalisti, no. oo (July 2010): 1, https://www. rivistaaic.it/images/rivista/pdf/TondidellaMurao1.pdf.

21 Arban, "Federal solidarity," 243 et seq.

22 Ottmann, "The Concept of Solidarity," 40; Willem T Eijsbouts and David Nederlof, "Editorial: Rethinking Solidarity in the EU, from Fact to Social Contact," European Constitutional Law Review 7, no. 2 (June 2011): 172; Arban, "Federal solidarity," 243. Ottmann, "The Concept of Solidarity," 39-40 and 44; Arban, "Federal solidarity," 243.

24 Arban, "Federal solidarity," 243 et seq.

25 Black's Law Dictionary, 9th ed, sub verbo "solidarity"; Arban, "Federal solidarity," 243.

26 Gonthier, “Liberty, Equality, Fraternity," 572.

27 Carlassare, "Solidarietà," 47, fn. 8.

28 Ottmann, "The Concept of Solidarity," 39; Arban, "Federal solidarity," 244.

29 Arban, "Federal solidarity," 244-245. 
defence or military service, whilst socio-economic solidarity comprises the duty to obtain proper education, to work, or to contribute to public expenses. ${ }^{30}$

Finally, solidarity may assume yet another specific meaning within the ambit of federal theory. Here, solidarity infuses provisions on equalisation payments, found in federal and quasi-federal states alike, whose purpose is to reduce the socio-economic imbalances or inequalities that may characterise the various regions and territories of the federation. Furthermore, federal solidarity is often linked to the doctrine of federal loyalty, whose roots can be traced back to the German notion of Bundestreue whose literal meaning can be rendered as fidelity, loyalty or faithfulness to the federal compact. ${ }^{31}$ As we will see in the remainder of the chapter, all these different nuances of the principle of solidarity can be found in the Italian constitutional text.

\subsection{Solidarity in the Italian Constitution: A Fundamental Principle and an Aspirational Value}

The 1948 Italian Constitution had immense practical and symbolic value at the time it was enacted. In fact, it was the first constitution that Italy had ever had, if we consider that the document previously in force - the Statuto Albertino - was a bill that King Carlo Alberto had granted in 1848 to the Kingdom of Piemonte and Sardegna: the Statuto was later extended to the whole peninsula after unification, and it remained in force also during the Fascist dictatorship, although it was mainly disregarded.

The 1948 Constitution was penned by the Constituent Assembly (Assemblea Costituente), whose members were democratically elected in June 1946 by universal suffrage with the specific task of drafting a new Constitution. Considering the time and circumstances in which it came into being, the 1948 Constitution represented, at the time, one of the most advanced examples of a post-war, post-dictatorship fundamental document, imbued with the highest and most elevated democratic values. Within this framework, the principle of solidarity immediately acquired a prominent place among the fundamental principles of the Constitution, an aspirational value informing the entire

30 Giovanna Razzano, "La materia concorrente della produzione, trasporto e distribuzione nazionale dell'energia nella recente giurisprudenza costituzionale, fra leale collaborazione e doveri di solidarietà," federalismi.it, no. 13 (June 2011): 12, http://www.federalismi. it $/$ ApplOpenFilePDF.cfm?artid=18394\&dpath=document\&dfile=28062011112903.pdf\&content $=\mathrm{La}+$ materia + concorrente + della + produzione, + trasporto $+\mathrm{e}+$ distribuzione + nazionale+dell\%27energia+nella+recente+giurisprudenza+costituzionale,+fra+leale+collaborazione+e+doveri+di+solidariet $\% \mathrm{C}_{3} \% \mathrm{AO}+-+$ stato+-+dottrina+-+, with references; Arban, "Federal solidarity," 245.

31 Arban, "Federal solidarity," 246 et seq. 
constitutional architecture. According to Tondi delle Mura, before representing a legal innovation, the constitutional entrenchment of solidarity marked a historical and cultural turn, at least compared to the previous legal system, thus transforming Italy into one of the most innovative and complete systems of the post-war era. ${ }^{32}$

Technically speaking, the principle of solidarity is explicitly spelled out only in two articles of the Constitution: article 2 (as one of the fundamental principles of the Italian Republic) and article 119 (with regards to fiscal federalism). However, both the ItCC and most constitutional scholars acknowledge that the spirit of solidarity in its broadest sense infuses several other provisions of the constitutional text. In fact, being based on the 'centrality of the human being', solidarity influences the dynamics of public and private powers, as well as of individual freedoms, ${ }^{33}$ and is the 'founding paradigm' upon which the unity of the state is premised. ${ }^{34}$

Article 2 Const. spells out solidarity in the following terms:

The Republic shall recognise and protect the inviolable rights of the person, both as an individual and in the social groups where human personality is expressed. The Republic expects that the fundamental duties of political, economic and social solidarity be fulfilled.

First, this article categorises two types of solidarity, political and socio-economic. As indicated supra, these duties generally refer to the responsibilities of the individual towards the community to which they belong, and include duties such as voting, accessing proper education, and working. ${ }^{35}$

Yet, this study of solidarity as a fundamental principle and aspirational value would not be complete without considering article 3 Const., as implicit in the principle of solidarity is the principle of equality. ${ }^{36}$

32 Tondi delle Mura, "La solidarietà fra etica ed estetica," $1-2$.

33 Tondi delle Mura, "La solidarietà fra etica ed estetica," 2.

34 Alessandro Morelli, "I principi costituzionali relativi ai doveri inderogabili di solidarietà," Forum di Quaderni Costituzionali, (April 2015): 3, http://www.forumcostituzionale.it/ wordpress/wp-content/uploads/2015/o4/morelli.pdf.

35 Razzano, "Materia concorrente," 12.

36 Article 3 Const. mandates that "[a]ll citizens shall have equal social dignity and shall be equal before the law, without distinction of gender, race, language, religion, political opinion, personal and social conditions. It shall be the duty of the Republic to remove those obstacles of an economic or social nature which constrain the freedom and equality of citizens, thereby impeding the full development of the human person and the effective participation of all workers in the political, economic and social organisation of the country.' 
Read together, articles 2 and 3 Const. are considered an expression of what the ItCC termed interpersonal or intergenerational solidarity. ${ }^{37}$ In this narrative, the 'centrality of the human being' is confirmed by the prominence that article 3 Const. gives to the concept of 'human dignity'. Constitutional scholars have defined it as a constitutional value that belongs to all human beings, regardless of their personal or social conditions, because the absence of dignity implies the 'negation of the same identity' of the individual: ${ }^{38}$ solidarity in this sense means the respect of the individuals in their physical being and needs. ${ }^{39}$

Solidarity and equality (understood also as prohibition of discrimination and absence of privileges $)^{40}$ in this way become indissolubly intertwined considering that individual and collective inequalities are no longer seen as a reason for social disintegration or personal impediment, but become the incentive to trigger public intervention and private participation, as one scholar has indicated. ${ }^{41}$ Equality is thus the 'engine' of solidarity. ${ }^{42}$ In this framework, solidarity and equality can be seen as principles complementing each other, as they contribute to regenerating each other and reciprocally give some concrete meaning. ${ }^{43}$ Furthermore, Morelli explains how solidarity and equality are intimately related in the sense that the constitutional entrenchment of equality alone would not be sufficient to ensure the cohesion of the many heterogeneous components of the state: this is why solidarity is also needed. ${ }^{44}$ Social and economic inequalities among citizens can be overcome only through an active participation of the state through the principle of solidarity. ${ }^{45}$

With regards to the type and meaning of social solidarity as spelled out in article 2 Const., the case law of the ItCC has offered interesting explanations that help better delineate the scope of this principle. In particular, in decision 75/1992 the ItCC confirmed that solidarity shall be read as a principle

37 The concept of interpersonal or intergenerational solidarity was used for the first time by the Italian Constitutional Court in decision 203/2013, para. 3.4.

38 Carlassare, "Solidarietà," 53.

39 Carlassare, "Solidarietà," 55 .

40 Carlassare, "Solidarietà," 52.

41 Tondi delle Mura, "La solidarietà fra etica ed estetica," 2.

42 Carlassare, "Solidarietà," 57.

43 Antonio Ruggeri, "Eguaglianza, solidarietà e tecniche decisorie nelle più salienti esperienze della giustizia costituzionale," Rivista dell'Associazione Italiana dei Costituzionalisti, no. 2 (May 2017): 5, https://www.rivistaaic.it/images/rivista/pdf/2_2017_Ruggeri.pdf. The intimate link between solidarity and equality, the latter to be understood as a value that contributes to infusing the former with some concrete meaning, is also stressed by Carlassare, "Solidarietà," 52 .

44 Morelli, "Principi costituzionali," 3.

45 Morelli, "Principi costituzionali," 6, with further references. 
positioned among the fundamental values of the Italian legal system to the point that it is solemnly protected and acknowledged - along with the inalienable rights of the individual - as the basis for social cohabitation and normatively canvassed in the constitutional text. This means that solidarity does not only have a descriptive meaning but is deeply imbued with a prescriptive value: consequently, while both solidarity and equality can be seen as aspirational and elevated principles, they are also prescriptive ones. ${ }^{46}$

This understanding of solidarity is further elaborated on in decision $500 /$ 1993, where the ItCC once again underlines the link existing between equality and solidarity. Solidarity thus acquires a modern gloss, as it goes beyond traditional conceptualisations premised on assistance and charity, or duties and obligations imposed by law, to become a way to concur and accomplish the substantial equality that allows the development of the personality as entrenched in article 3 Const. Its purpose is to reach the necessary collaboration to achieve common goods such as scientific research, cultural and artistic enhancement, and health and wellbeing for all individuals. The court thus confirms the public value of the individual and associative expressions of solidarity: I will return to this aspect when discussing solidarity in conjunction with subsidiarity.

Although article 2 Const. is the only provision where solidarity as a fundamental principle is explicitly spelled out (along with article 119 Const. on fiscal federalism), the spirit of solidarity clearly infuses other parts of the Constitution, especially those related to socio-economic rights. For example, article 4 Const. recognises and protects the right of all citizens to work, where work is construed not only as a right but also a duty so that, through their working activity, each individual can contribute to the 'material or spiritual progress of society' ${ }^{47}$ Solidarity in relation to work performance is implicit also in article 36(1) Const. providing that workers are entitled to a salary proportional to the quantity and quality of the job performed, but in any event sufficient to guarantee to the worker and their family a free and decent life. Similarly, article 37 Const. mandates for equal salary treatment for working men and women for the same job and protects the working conditions of women in fulfilling their 'essential role in the family' and in ensuring 'appropriate protection for the mother and child'. The spirit of solidarity also prominently permeates article 38 Const. in providing for specific welfare and/or support services to citizens

46 Carlassare, "Solidarietà," 46.

47 Incidentally, labour also occupies a prominent place in the constitutional text, considering that it is the foundation upon which the whole Italian Republic is anchored: in fact, article 1 Const. mandates that 'Italy is a democratic republic founded on labour'. 
unable to work and without means of subsistence; accident, illness, disability, old age and involuntary unemployment support to workers; and vocational training and education to disabled and handicapped persons. This provision is not to be read as an expression of the spirit of 'brotherhood' but as a clear duty of the state. ${ }^{48}$

Within the ambit of freedom of religion, article 8 Const. mandates that 'all religious denominations shall be equally free before the law' and this provision, read together with the prohibition against religious discrimination of article 3 Const., shall be construed as another example of solidarity, a value that religious intolerance destroys. ${ }^{49}$

With regards to family matters, article 29 Const. acknowledges and protects the rights of the family and the moral and legal equality of spouses, and this is usually construed as an example of the interpersonal or intergenerational solidarity enunciated above. Article 31(1) Const., provides that "[t]he Republic shall assist the development of a family and the fulfilment of its duties, with particular consideration for large families, through economic measures and other benefits'.

Article 32(1) Const. is also construed as entrenching solidarity-based values in protecting health as a fundamental right of the individual and as a collective interest and in guaranteeing free medical care for the indigents (so-called 'health solidarity').

Implicitly, solidarity also infuses article 34 Const. on the right to education, by mandating that primary education is compulsory and gratuitous, and that all capable and deserving students have the right to pursue their studies regardless of their economic capacity, as the State implements a system of scholarships, allowances and benefits to less advantaged families.

The right to vote enshrined in article 48 Const. is also seen as an expression of political solidarity entrenched in article 2 Const. Finally, article 53(1) Const. spells out a duty usually referred to as 'social solidarity' when it mandates that '[e]very person shall contribute to public expenditure in accordance with their capabilities. ${ }^{50}$ Social solidarity also permeates article 54 Const. providing for a duty to all citizens to 'be loyal to the Republic and to uphold its Constitution and laws'.

This reading of articles 2 and 3 Const. (along with the other provisions on socio-economic and fundamental rights listed above) shows that solidarity shall be construed both as a right and a duty: on the one hand, by mandating

\footnotetext{
48 Carlassare, "Solidarietà," $57-58$.

49 Carlassare, "Solidarietà," 55.

50 See also ItCC ruling $270 / 2007$.
} 
that the Italian Republic expects the fulfilment of the fundamental duties of political, economic and social solidarity, article 2 Const. goes beyond the meaning of mere voluntary or charitable action ${ }^{51}$ and is rather construed as a duty engaging both the state and the individuals to act according to certain canons. On the other hand, in the provisions on socio-economic rights, solidarity becomes a right for the individual to expect some specific performance from public institutions that thus have a duty to act on the basis of solidarity and equality.

Issues of interpersonal or intergenerational solidarity and equality ex art. 2 and 3 Const. have played a prominent role in Italian constitutional case law over these past few years, especially with regards to immigration issues in relation to fundamental rights. As an example, in ruling 192/2006 the ItCC ruled on solidarity in its connection to the right to health embedded in article 32 Const. The Justice of the Peace of Genova questioned the constitutional legitimacy of a specific provision contained in state law 286/1998 on immigration, whereby an expulsion decree could be executed also towards a (non-EU) foreign national, illegally present in the Italian territory, in a relationship with a pregnant Italian citizen, thus preventing him from providing adequate moral and material care and support to the woman. According to the trial judge, such a decree would infringe upon articles 2 and 32 Const. as it would limit or violate, among other things, the mandatory duty of solidarity linked to the right to health. In rejecting the claim, the ItCC held that the reasons of human solidarity are not in contrast with immigration laws enacted to provide for organised migratory flows and for the adequate reception and integration of foreign nationals. In confirming the above statement, rulings 64/2011 and 144/2011 further explained that solidarity is, however, expressed in the legislative provisions applying also to illegal immigrants the norms on refugee aid and international protection and in non-criminalising all human aid and assistance given in Italy to foreign individuals in such need; decision 250/2010 reached similar conclusions.

This overview of solidarity and equality as percolating from articles 2 and 3 Const. shows that the type of interpersonal or intergenerational solidarity is a well-articulated principle in the Italian constitutional framework: in fact, it moves vertically from the individual to the community and central institutions and vice versa from central institutions to individuals, in a dynamic movement that brings reciprocal benefits to the parties involved.

$5^{1} \quad$ Gianluca Bascherini, "La solidarietà politica nell'esperienza costituzionale repubblicana," Costituzionalismo.it, no. 1 (June 2016): 126, http://www.costituzionalismo.it/download/ Costituzionalismo_201601_565.pdf. 


\section{Solidarity and Federalism}

\subsection{In General}

When discussing solidarity, the focus is usually on fundamental or socioeconomic rights and duties: in this sense, the study on solidarity and equality carried out so far in the Italian context is a good example of this common approach. However, I explained above that, aside from it being a general and/ or aspirational principle with a normative and prescriptive value, solidarity as a legal concept may acquire a very distinctive nuance within the ambit of federal theory: an analysis of solidarity would thus be incomplete without also considering this important facet of the principle.

In section 1, I argued that, while Italy is not a fully-fledged federation, there is a longstanding and quite contested relationship between solidarity and federalism. Among other things, federalism implies a decentralisation of powers, including fiscal powers, since the fiscal autonomy of the peripheral units is one of the elements that distinguishes a federal state from a unitary one. It is exactly this fiscal autonomy of the peripheral units that has created problems in Italy in the past. To better understand this, we need to go back to the socioeconomic asymmetries characterising Italy.

Solidarity has emerged almost as an obsessive concern for Italian decision makers since unification in the 186 os, particularly because of the socioeconomic disparities existing between the richer regions in the North and the poorer areas in the South, so that solidarity-based mechanisms have persistently been invoked to contain these imbalances. Before the constitutional reform of 2001, one of the major worries in political circles was that a transformation of Italy into a fully-fledged federation would amplify, rather than reduce, the socio-economic disparities between the North and the South. In other words, the fear was that federalism would be against the solidarity-based interests linking regions to each other and to the state. ${ }^{52}$

When in the 1990 os the $\mathrm{LN}^{53}$ included federalism in its political agenda, it was understood, by non-LN voters, as the expression of a certain economic and political interest representative of the wealthier Northern Italy only, to the detriment of the rest: this contributed to the lack of popularity of federal ideas outside traditional LN strongholds. The LN fed into the North/South divide in claiming that Rome used money coming from taxpayers in the North to subsidise the South without giving back anything to the allegedly most hard-working

\footnotetext{
$5^{2}$ Lecours and Arban, "Italy and Nepal," 187 et seq.

53 As discussed above, the LN is a political party whose supporters mainly resided in the wealthier North.
} 
part of the country. The LN insisted that each region should be responsible for its own money and deal with all local aspects without depending on interventions from the centre. But the consequences of this federal project were seen as dire for the South: by vesting individual regions with more powers, especially in the fiscal domain, the wealthier areas in the North would risk becoming even wealthier to the detriment of the poorer regions in the South, severely penalised in such a scenario as they could no longer rely on central transfers. In other words, the federal ideas advocated by the LN were understood by many as the expression of the Northern selfishness towards the South that would run against the spirit of solidarity and equality. 54

When in 2001 Title V of the Constitution was amended, it did not transform Italy into a full-fledged federation, but it strengthened the (legislative and administrative) powers of regional governments and provided for a mild form of fiscal federalism. This is important for our narrative, considering that constitutional provisions on fiscal federalism exude solidarity concerns. When discussing the principle of solidarity in its specific connection with Italian regionalism, the following articles of the Italian Constitution need to be discussed: article 117 on the division of legislative powers between the regions and the central government; article 118 on horizontal and vertical subsidiarity, article 119 on fiscal federalism, and article 120 on loyal cooperation.

\subsection{Solidarity and Division of Powers (Article 117 Const.)}

Article 117 Const. enshrines the division of legislative powers between the two levels of government: article 117 (2) Const. lists all subject matters falling within the exclusive legislative powers of the central government; article 117(3) Const. enumerates the subject matters falling within the concurrent jurisdiction of central and regional government, ${ }^{55}$ while article 117 (4) Const. reserves all residual powers (e.g. powers not specifically detailed in the constitutional text) to regional governments. General solidarity and equality concerns, however, lurk behind some of the choices made by the constitutional legislator in dividing powers between central and regional governments. For example, article $117(2)(l)$ Const. provides that the central government has exclusive jurisdiction over civil and criminal law and procedure, as well as the administrative judicial system; article $117(2)(m)$ Const. reserves to the exclusive jurisdiction of the central government the power to set the basic levels of benefits for the enjoyment of

54 Lecours and Arban, "Italy and Nepal," 187 et seq.

55 Article 117 (3) Const. explains that when powers are concurring, State (or central) legislation is responsible for laying down fundamental principles, whilst regional governments are vested with the actual legislative powers. 
social and civil rights; articles $117(2)(n)$ and (o) Const. assign to the exclusive power of the central state the regulation of general provisions on education and social security, respectively; article $117(2)(s)$ Const. reserves as the exclusive competence of the national Parliament the power to legislate in areas such as environmental protection, ecosystem and cultural heritage. ${ }^{56}$

In the specific context of the division of powers, the principle of solidarity has been used by the ItCC as a justification for deviating from the way powers are distributed between the state and regional governments. For example, in ruling 10/2010 the ItCC upheld a state intervention that introduced a socalled social card in 2008 to help disadvantaged people buy necessary goods, in apparent violation with the regional power over services and public assistance. The ItCC justified the state intervention by resorting to the principles of solidarity and equality to function as some sort of 'national interest' clause. ${ }^{57}$

\subsection{Solidarity and Subsidiarity (Article 118 Const.)}

Among the many novelties introduced by the 2001 constitutional reform, there was the entrenchment of the principle of subsidiarity in article 118. Article 118(1) Const. provides that administrative functions belong to the level of government closest to the citizens (e.g. municipalities), unless they are attributed to a higher level of government (provinces, metropolitan cities, regions, or the State) if there is a need for uniform interpretation in a given subject matter pursuant to the principles of subsidiarity, differentiation, and adequacy (or proportionality). Article 118(1) Const. thus entrenches subsidiarity in its most classic understanding, as a tool where all the administrative functions that are best handled locally are assigned to the level of government closest to citizens.

For purposes of our discussion, however, it is article 118(4) Const. that acquires an interesting gloss. In fact, this provision mandates that

The State, regions, metropolitan cities, provinces and municipalities shall promote the autonomous initiatives of citizens, both as individuals and as members of associations, relating to activities of general interest, on the basis of the principle of subsidiarity.

56 This exclusive reservation has been explained by the need to set uniform terms of environmental protection across the national territory based on the need to offer and guarantee the use of water resources according to solidarity-based criteria (among other things): ex multis, see ItCC rulings 93/2017 and 246/2009.

57 Angelo Schillaci, "Governo dell'economia e gestione dei conflitti nell'Unione Europea: Appunti sul principio di solidarietà," Costituzionalismo.it, no. 1 (March 2017): 40, http://www.costituzionalismo.it/download/Costituzionalismo_201701_6o4.pdf. 
This provision enshrines the so-called horizontal aspect of subsidiarity, one that relates to the 'sharing of competences and initiatives between public and private actors' 58 so that, in this sense, 'subsidiarity could be conceived like a sort of 'division of labor' between public sector and civil society (person, family, non-profit organization, market) ${ }^{59}$ Consequently, on the basis of subsidiarity as enshrined in the Constitution, the State and other local governments 'shall promote the autonomous initiatives of citizens, both as individuals and as members of associations, relating to activities of general interest'. As explained by one scholar, this provision 'aims to promote general interests' and is addressed to 'public authorities and private bodies'.60

Subsidiarity implies cooperation, and so it can be seen here as a cooperative principle: in this sense, the principle is linked to solidarity understood as cooperation. ${ }^{61}$ Some theorists confirm this allegation and argue that this specific entrenchment of subsidiarity can be conceived as an expression of solidarity: in fact, article 118(4) Const. invites public and private actors alike to collaborate in the 'arrangement of services to the individual, while respecting the complexity of the needs of each single beneficiary'. ${ }^{2}$ Consequently, article 118(4) Const. entrenches the idea of solidarity between the individual and the community: 63 in this sense, it could be understood as an expression of article 2 Const. in the part where it provides for the recognition and protection of inviolable basic rights of the individual as part of the social groups in which one's personality is expressed.

\subsection{Solidarity and Fiscal Federalism (Article 119 Const.)}

Because of the specific nature of the constitutional and political debate over federalism, it is with regard to article 119 Const. that issues of solidarity and equality prominently come into play. Article 119 Const. on fiscal federalism was one of the most notable novelties of the 2001 constitutional reform. The first two paragraphs of article 119 Const. mandate that regions (along with other local self-governments) shall enjoy financial autonomy of revenues and

$5^{8}$ Alessandro Colombo, “The 'Lombardy Model': Subsidiarity-informed Regional Governance," Social Policy and Administration 42, no. 2 (April 2008): 182; see also Erika Arban, "Re-centralizing Subsidiarity, Interpretations by the Italian Constitutional Court," Regional and Federal Studies 25, no. 2 (2015): 129.

59 Colombo, "The Lombardy Model," 182; Arban, "Re-centralizing Subsidiarity," 129.

6o Claudia Tubertini, "Public Administration in the Light of the New Title V of the Italian Constitution," European Public Law 12, no. 1 (2006): 40.

61 Schillaci, "Governo dell'economia," 41.

62 Tondi delle Mura, "La solidarietà fra etica ed estetica," 10.

63 Morelli, "Principi costituzionali," 4. 
expenses, and shall set and levy taxes and collect revenues of their own, in compliance with the Constitution, with tax system principles and with the principles of coordination of state finance; furthermore, regions and other local entities also share in the tax revenues related to their respective territories. Article 119(3) Const. introduces equalisation payments, a solidarity-based tool that is common to several federal or decentralised systems: the paragraph mandates that national legislation shall provide for equalisation funds (with no allocation constraints) for territories having a lower per-capita taxable capacity. As the constitutional text further provides (article 119(4) Const.), and as the same ItCC has explained, all revenues that regions (and other local governments) raise in accordance to articles 119(2)(3) Const. exhaust the list of resources that allow them to fully finance the public functions attributed to them. However, article 119(5) Const. further provides that the central government shall allocate supplementary resources and adopt special measures in favour of specific regions or other local governments to promote economic development, social cohesion and solidarity, to reduce economic and social imbalances, to foster the exercise of individual rights or to achieve goals other than those pursued in the ordinary implementation of their functions. I will revert to this paragraph in a moment, but to complete the overview of this constitutional provision, it shall be recalled that article 119(6) Const. mandates that regions and other local governments have their own properties and may resort to indebtedness only as a means of funding investments, while state guarantees on loans contracted for this purpose are not admissible.

We noted above that article 119 Const. was one of the most important innovations introduced by the 2001 constitutional amendment, but it did not come without concerns for solidarity. To better clarify this point, it might be helpful to point out how the previous version of article 119 Const. had a rather different gloss, as it specifically targeted Southern regions in requiring the national government to statutorily grant special contributions to individual regions, particularly in order to valorise the Mezzogiorno and the Islands. ${ }^{64}$ In any event, contrary to the interpersonal or intergenerational connotation of solidarity enshrined in article 2 Const. and outlined above, article 119 Const. relates to a more 'public' aspect of the principle, as this provision requires the central government to play a pivotal role in assisting disadvantaged regions and containing the imbalances between richer and poorer areas through equalisation

64 Patroni Griffi, "Federalismo e Mezzogiorno," 3.

Mezzogiorno is a term commonly used to refer to the South of Italy, whereas the term Islands usually refers to Sicilia, Sardegna, but also to the myriad of smaller islands positioned in the Mediterranean Sea that are also considered disadvantaged. 
payments. However, it is always the principles of solidarity and equality entrenched in articles 2 and 3 Const. that constitute the basis for solidarity in article 119 Const. In other words, the exact contours of solidarity are often porous, as the fiscal component is never completely separated from the more moral nuance of the principle. This means that the various facets of solidarity overlap, making it a very fluid value.

As anticipated above, it is the allocation of supplementary resources and implementation of special financial interventions in favour of specific local governments (article 119(5) Const.) that has raised most concerns, and the ItCC has been called into play many times to clarify the scope of this provision. In fact, regional governments have often lamented that the central state has resorted to article 119(5) Const. to control regional or local resources, even when this was prohibited by the Constitution. In ruling 16/2004, for example, Regione Umbria questioned the constitutional validity of a few provisions included in the 2002 Budgetary Law, in particular in the part where it created a state Fund aimed at financing the adoption of development and renovation programs for municipal territories. A significant portion of this Fund was reserved for smaller municipalities, particularly those located in Southern Italy. According to Regione Umbria, the creation of this Fund infringed upon, among other things, the fiscal autonomy of regions as the Fund could not be traced back to the type of interventions listed in article 119(5) Const. Rather, it was destined to unspecified recipients, even if the provision seemed to favour smaller municipalities in the South. The ItCC explained that the central government cannot directly finance interventions (with allocation constraints) in favour of municipalities, for activities that fall within the jurisdiction of the latter and that are outside the subject matters of exclusive national competence; likewise, the state cannot directly finance special interventions in favour of certain municipalities as per article 119(5) Const. In particular, it is not admissible for the state to provide for such financing in areas belonging to the exclusive competence of the regional governments. Furthermore, the types of intervention indicated in article 119(5) Const. shall be considered additional to the integral financing provided for by article 119(4) Const. of tasks belonging to local governments. They shall refer to equalisation goals or goals other than the normal performance of their functions and shall be destined to specifically identified local governments. In light of the above, the ItCC concluded that the challenged state provision did not comply with constitutional requirements, it being a mere direct transfer of state funds from the state to municipalities for purposes set by state law, and foreign to the constitutional architecture painted by article 119 Const. Similar arguments were confirmed in ItCC rulings $37 / 2004$ and 49/2004. 
ItCC ruling 222/2005 also falls along the same lines: here, the Court explained that, within the framework sketched by article 119 Const., the central government cannot establish its own financial support in subject matters falling entirely within regional (exclusive) legislative jurisdiction; neither can it establish sectoral funds to finance regional activities. The only exceptions in this regard are those enshrined in article 119(5) Const., allowing the central government to finance activities that would normally fall within exclusive regional competences, as long as the goal is to promote economic development, socio-economic cohesion and social solidarity.

With ruling 451/2006, the ItCC upheld a state legislative provision creating a fund for special housing rent: the objective of this intervention was to broaden the number of beneficiaries of subsidised rate leases and thus remove barriers to the enjoyment of housing especially in those territories where rents are particularly high.

With ruling 45/2008, the ItCC upheld as complying with article 119(5) Const. a state law providing for the allocation, by the Ministry of Health, of significant sums of money to Southern regions to ensure the continuation of special interventions for the diffusion of oncological screening. The ItCC saw this as an example of a special intervention pursuant to article 119(5) Const. as it aimed at fostering social solidarity, and the effective exercise of individual rights.

An interesting ruling of the ItCC on solidarity and article 119 Const. is 118/ 2015: here, the court declared the unconstitutionality of some sections of a Regional Law of Veneto calling, among other things, a referendum asking citizens whether they would be in favour of keeping locally at least $80 \%$ of the taxes paid every year to the state, and whether the region should keep at least $80 \%$ of the taxes levied in the regional territory. The ItCC argued that these two questions had the effect of significantly altering the balance of public finance, thus jeopardising the solidarity-based links between the people living in the region and the state. Among other things, the proposals affected some structural elements of the national system of financial planning necessary to ensure the cohesion and solidarity in the state, as well as its legal and economic unity. The two questions implicitly impacted solidarity among regions, between the region and the state, and even among individuals because, as the court indicated, the referendum proposed to subtract a significant portion of public finance to direct it to the exclusive advantage of a single region and its inhabitants.

To complete this survey of solidarity-based mechanisms as enshrined in article 119 Const., one last question needs to be asked: does article 119 Const. extend this type of solidarity duty also horizontally, e.g. among regions? This question was addressed by the ItCC in ruling 176/2012, when the Court was 
called upon to decide whether article 119(5) Const. also encompasses a duty upon 'virtuous regions' to support less advantaged regions, so that the duty to support less developed regions falls not only within the jurisdiction of the central government but also that of richer regions. The ItCC clarified that equalisation and other solidarity-based mechanisms can only come from the central government (thus vertically), as the intention of the constitutional legislator was to provide only for vertical equalisation payments.

\subsection{Solidarity and Loyalty (Loyal Cooperation) (Article 12o(2) Const.)}

As I have extensively illustrated elsewhere, federal theory often links solidarity to the doctrine of federal loyalty or Bundestreue, the latter being a notion developed in German constitutionalism and reflecting an idea of loyalty or faithfulness to the federal compact. ${ }^{65}$ Bundestreue implies, among other things, some form of cooperation in trust and good faith between central and peripheral governments, including the duties to support and consult one another and coordinate their actions. ${ }^{66}$ This explains why cooperative federalism is often construed as an expression of Bundestreue. Yet, the two are not perfectly identical: in fact, Bundestreue 'is not exhausted in the idea of intergovernmental relations and overlapping jurisdiction' between central and peripheral governments, as it also includes dimensions traceable back to mutual aid and assistance that are well incarnated by the concept of solidarity. ${ }^{67}$

In article $120(2)$ Const., as amended in 2001, specific reference is made to loyal cooperation in the ambit of 'substitution powers' that the central government can use in the event the periphery fails to properly exercise these powers. ${ }^{6}$

According to the ItCC, this article protects the legal and economic unity of the state, ${ }^{69}$ and it can be seen as another example of solidarity promoting

65 Arban, "Federal solidarity," 247.

66 Dirk Brand, "The South African Constitution - Three Crucial Issues for Future Development," Stellenbosch Law Review 9, no. 2 (1998): 186; Arban, "Federal solidarity," 247.

67 Arban, "Federal solidarity," 252.

68 More specifically, article $120(2)$ Const. mandates that " $\mathrm{t}$ ] he Government can subsume the authority of a Region, metropolitan city, province or municipality if it fails to comply with international rules and treaties or EU legislation, or in case of grave danger for public safety and security, or whenever such action is necessary in order to preserve legal or economic unity and in particular to ensure the minimum level of benefits relating to civil and social entitlements, regardless of the geographic borders of a local authority. The law shall lay down the procedures to ensure that subsidiary powers are exercised in compliance with the principles of subsidiarity and loyal co-operation'.

69 ItCC ruling 239/2015. 
equality, as it requires the state to collaborate with regions on an equal basis: the ItCC has explained in ruling 222/2005 that loyal cooperation requires a real and current agreement between the state and regional governments in order to be complied with. In other words, it is not sufficient that the central government 'hears' regional governments, because in such situations the constitutional autonomy recognised for regions would be seriously restrained. Without a traditional federal senate or upper chamber in the Italian legal system, the ideal locus for the various levels of government (state and regions) to dialogue and find a common understanding is the State-Regions Conference or the Unified Conference. ${ }^{70}$

\subsection{Other Solidarity-Based Decisions in State-Regions Controversies}

To complete this overview of solidarity, it is useful to briefly discuss two other ItCC rulings where solidarity as a principle of equality was called into question in state-region controversies.

In the aftermath of the 2008 worldwide economic crisis, driven by the need to improve the overall credibility of Italy in the global context, a constitutional law was passed in 2012 to amend some sections of the Constitution: the string of amendments mainly dealt with the constitutional entrenchment of the principles of balanced budget and debt sustainability for all tiers of government, along with the respect of EU obligations. In ruling 88/2014 the ItCC made reference to these amendments and argued that the fulfilment of the obligation of public debt sustainability should be construed as a responsibility that, along with the principles of intergenerational solidarity and equality of articles 2 and 3 Const., belongs not only to public institutions but also to each individual citizen when acting towards the others, including future generations. As explained by one scholar, the rationale for this constitutional change was that, if public debt becomes unsustainable, the responsibility for this falls on everyone, private individuals and public bodies alike: for this reason, the twin values of solidarity and equality should inform all behaviours. ${ }^{71}$ All citizens thus bear the sacrifice to guarantee the sustainability of public debt: this duty is grounded in the constitutional principles of solidarity and equality. ${ }^{72}$

70 See ex multis ItCC ruling $297 / 2012$. The 'system of conferences' was introduced in Italy in 1997, and it includes the permanent state-regions conference (composed by the president of each region, of each autonomous province, by the president of the council of ministers and by the ministers involved in the specific question) and the state-cities conference; the unified conference is composed by the members of both state-cities and state-regions conference.

71 Ruggeri, "Eguaglianza," 22.

72 Ruggeri, "Eguaglianza," 22. 
Another interesting ItCC ruling is 331/2010: here, the Italian government questioned the constitutionality of a string of provisions contained in various regional laws and pertaining to the decision, made by some regional governments, to exclude regional territories from the installation of nuclear plants and storage unless a preliminary agreement was reached between regions and the state regarding the specific location of these plants. The ItCC ruled against these regional laws on various grounds, but most importantly was the argument whereby regions cannot unilaterally avoid the sacrifices that come with the enactment of a state law with a national scope (in the specific case, the sector of energy production), because this would violate the mandatory duties of socioeconomic solidarity entrenched in the Constitution. Solidarity was invoked in this case to soften the self-centred behaviours of certain regions faced with legislation enforced at the national level in the interest of the whole country.

In conclusion, it is worth noting that scholars like Patroni Griffi harshly criticised many novelties introduced in 2001 that, in his opinion, betray solidarity, in particular the new fiscal system introduced by article 119 Const.: ${ }^{73}$ in fact, he contends that asymmetrical federalism, or any form of federalism that puts territories in competition with one another, should be rejected as non-responding to the spirit of solidarity that animates the constitutional framework. ${ }^{74}$ The only form of federalism acceptable for Italy would be 'unitary', in the sense of reducing asymmetries and inequalities among the various territories. ${ }^{75}$ The risk of creating territorial asymmetries requires finding a balance between territorial pluralism, solidarity, subsidiarity and equality. ${ }^{76}$ In this sense, scholars have explained that the constitutional reform of 2001 was meant to 'delineate some sort of Italian way to a unitary and solidarity-based federalism. ${ }^{77}$

\section{Conclusion: Solidarity as a Principle of Equality}

Prominently entrenched in article 2 Const. among the fundamental principles of the Constitution, solidarity crosses the whole constitutional text, ${ }^{78}$ thus

73 Patroni Griff, "Federalismo e Mezzogiorno," 6.

74 Patroni Griffi, "Federalismo e Mezzogiorno," 6.

75 Schillaci, "Governo dell'economia," 42. Although the use of the term 'unitary' to define federalism might appear contradictory, the author probably refers to a form of 'symmetrical' or 'uniform' federalism.

76 Schillaci, “Governo dell'economia," 38.

77 Gian Candido De Martin, "Riforme autonomistiche incompiute e problemi culturali," Amministrazione in Cammino (May 2013): 2, https://www.amministrazioneincammino. luiss.it/wp-content/uploads/2013/o1/GCDeMartin_studi-onoreN_Greco.pdf.

78 Carlassare, "Solidarietà," 46. 
informing not only interpersonal and intergenerational relationships, but also the relationships between public institutions and individuals and, eventually, between the various levels of government, both in the sense of (federal) solidarity and of Bundestreue (or loyal cooperation). This chapter attempted to show how the principle of solidarity plays a crucial role in the Italian legal and constitutional architecture: as such, solidarity can be construed as an aspirational principle informing not only the constitutional provisions on fundamental and socio-economic rights, but also the constitutional provisions on autonomy and federalism. In other words, in the intentions of the drafters, solidarity was not an abstract or empty value, but an ideal that should acquire concrete sense in connection with the twin principle of equality.

In conclusion, this chapter advances the idea that solidarity as an aspirational principle tends to identify two major values: equality and unity. In fact, it appears rather clearly that, intrinsic in the notion of solidarity is a sense of equality, so that solidarity can be construed as a principle of equality. The interpersonal or intergenerational solidarity emerging from the combined reading of articles 2 and 3 Const. postulates the ideal of equality of all individuals in the enjoyment of their fundamental individual rights, including socioeconomic rights. Furthermore, the solidarity-based mechanisms delineated in the various paragraphs of article 119 Const. are premised on the assumption that all regions should enjoy, as much as possible, the same equal conditions in terms of socio-economic and fiscal powers, so that solidarity can be construed as a tool to further fiscal equality and reduce fiscal imbalances. Finally, solidarity in the specific understanding of loyal cooperation as enshrined in article $120(2)$ Const. seems to suggest that the central government shall take into account the role of regions, almost as if these two levels of government were equal in decision-making.

Yet, solidarity is also a principle of unity: in fact, it plays a very important role as an aspirational concept that can be used to pursue and foster social cohesion in a state such as Italy, characterised by deep socio-economic asymmetries. In this sense, solidarity can be read as an aspirational constitutional principle that identifies a common value to seek the unity of the people and of the various units that compose the state even under conditions of profound diversity.

Unfortunately, however, despite the prominence and elevated moral and legal value that the Constitution assigns to solidarity as a principle of equality, inequalities and obstacles (that the state has a constitutional duty to remove) have dramatically increased over these past few decades in Italy. ${ }^{79}$ 
The North-South socio-economic cleavage seems without effective solutions, and is exacerbated by the role played by corruption in local and national politics. But inequalities are not a prerogative of Northern vs. Southern regions, as they increasingly shape the social sphere, thus jeopardising social cohesion. In times of global crisis such as we are currently experiencing, some scholars invite us to look back at the Constitution and its aspirational values of solidarity and equality as guidance in personal and institutional decisions to be made. ${ }^{80}$

\section{Bibliography}

Amoretti, Ugo. "A new look at federalism: Italy decentralizes." Journal of Democracy 13, no. 2 (April 2002): 126-140.

Arban, Erika. "Re-centralizing Subsidiarity, Interpretations by the Italian Constitutional Court." Regional and Federal Studies 25, no. 2 (2015): 129-144.

Arban, Erika. "Exploring the Principle of (Federal) Solidarity." Review of Constitutional Studies 22, no. 2 (September 2017): 241-26o.

Arcioni, Elisa, and Adrienne Stone. "The Small Brown Bird: Values and Aspirations in the Australian Constitution." International Journal of Constitutional Law 14, no. 1 (January 2016): 60-79.

Baldini, Gianfranco, and Brunetta Baldi. "Decentralization in Italy and the Troubles of Federalization." Regional and Federal Studies 24, no. 1 (2014): 87-108.

Barbera, Augusto. "Da un federalismo 'insincero' ad un regionalismo 'preso sul serio'? Una riflessione sull'esperienza regionale." Forum di Quaderni Costituzionali (October 2012). http://www.forumcostituzionale.it/wordpress/images/stories/pdf/ documenti_forum/paper/o34o_barbera.pdf.

Bascherini, Gianluca. "La solidarietà politica nell'esperienza costituzionale repubblicana." Costituzionalismo.it, no. 1 (June 2016): 125-162. http://www.costituzionalismo. it/download/Costituzionalismo_2016o1_565.pdf.

Brand, Dirk. "The South African Constitution - Three Crucial Issues for Future Development." Stellenbosch Law Review 9, no. 2 (1998): 182-195.

Caravita, Beniamino. "Italy: Between the Hybrid State and Europe's Federalizing Process." In Routledge Handbook of Regionalism and Federalism, edited by John Loughlin, John Kinkaid and Wilfried Swenden, 287-301. London and New York: Routledge, 2013.

Caretti, Paolo, and Giovanni Tarli Barbieri. Diritto regionale. Torino: Giappichelli, 2012.

80 As an example, see Bascherini, "Solidarietà," 126. 
Carlassare, Lorenza. "Solidarietà: un progetto politico." Costituzionalismo.it, no. 1 (May 2016): 45-67. http://www.costituzionalismo.it/download/Costituzionalismo_ 2016o1_559.pdf.

Cartei, Gian Franco, and Vincenzo Ferraro. "Reform of the Fifth Title of the Italian Constitution: A First Step Towards a Federal System?." European Public Law 8, no. 4 (2002): 445-454.

Colombo, Alessandro. "The 'Lombardy Model': Subsidiarity-informed Regional Governance." Social Policy and Administration 42, no. 2 (April 2008): 177-196.

Dapelo, Carlo. "The Trends towards Federalism in Italy." St. Thomas Law Review 15, no. 2 (Winter 2002): $345^{-3} 5^{2}$.

Del Duca, Louis, and Patrick Del Duca. "An Italian Federalism? The State, its Institutions and National Culture as Rule of Law Guarantor." American Journal of Comparative Law 54, no. 4 (Fall 2006): 799-841.

De Martin, Gian Candido. "Riforme autonomistiche incompiute e problemi culturali." Amministrazione in Cammino (May 2013). https://www.amministrazioneincammino.luiss.it/wp-content/uploads/2013/o1/GCDeMartin_studi-onoreN_Greco.pdf.

Eijsbouts, Willem T, and David Nederlof. "Editorial: Rethinking Solidarity in the EU, from Fact to Social Contact." European Constitutional Law Review 7, no. 2 (June 2011): 169-172.

Eva, Fabrizio. "Deconstructing Italy: (Northern) Italians and their new perception of territoriality." GeoJournal 48, no. 2 (1999): 101-107.

Fabbrini, Sergio, and Marco Brunazzo. "Federalizing Italy: The Convergent Effects of Europeanization and Domestic Mobilization." Regional and Federal Studies 13, no. 1 (Spring 2003): 100-120.

Gonthier, Charles D. "Liberty, Equality, Fraternity: The Forgotten Leg of the Trilogy, or Fraternity: the Unspoken Third Pillar of Democracy." McGill Law Journal 45, no. 3 (June 2000): 567-589.

Groppi, Tania, and Nicoletta Scattone. "Italy: The Subsidiarity Principle." International Journal of Constitutional Law 4, no. 1 (January 2006):131-137.

Lecours, André and Erika Arban. "Why Federalism Does Not Always Take Shape: The Cases of Italy and Nepal." Regional and Federal Studies 25, no. 2 (2015): 183-201.

Maiden, Martin. "The Definition of Multilingualism in Historical Perspective." In Multilingualism in Italy, Past and Present, edited by Anna Laura Lepschy and Arturo Tosi, 31-46. Oxford: European Humanities Research Centre of the University of Oxford, 2002.

Mazzoleni, Martino. “The Italian Regionalization: A Story of Partisan Logics." Modern Italy 14 , no. 2 (May 2009): 135-150.

Morelli, Alessandro. "I principi costituzionali relativi ai doveri inderogabili di solidarietà." Forum di Quaderni Costituzionali (April 2015). http://www.forumcostituzionale.it/wordpress/wp-content/uploads/2015/o4/morelli.pdf. 
Ottmann, Juliane. "The Concept of Solidarity in National and European Law: The Welfare State and the European Social Model." Vienna Journal on International Constitutional Law 2, no. 1 (January 2008): 36-48.

Patroni Griffi, Andrea. "Federalismo, Mezzogiorno e sviluppo solidale." Forum di Quaderni Costituzionali. http://www.forumcostituzionale.it/wordpress/images/ stories/pdf/documenti_forum/paper/o247_patroni_griffi.pdf.

Pinelli, Cesare. "The 1948 Italian Constitution and the 2006 Referendum: Food for Thought." European Constitutional Law Review 2, no. 3 (October 2006): 329-340.

Razzano, Giovanna. "La materia concorrente della produzione, trasporto e distribuzione nazionale dell'energia nella recente giurisprudenza costituzionale, fra leale collaborazione e doveri di solidarietà." federalismi.it, no. 13 (June 2011). http:// www.federalismi.it/ApplOpenFilePDF.cfm?artid=18394\&dpath=document\&dfile $=28062011112903 \cdot p d f \&$ content $=\mathrm{La}+$ materia + concorrente + della + produzi one,+trasporto+e+distribuzione+nazionale+dell\%27energia+nella+recente+giurisprudenza+costituzionale, + fra+leale + collaborazione $+\mathrm{e}+$ doveri $+\mathrm{di}+$ solidariet $\% \mathrm{C}_{3} \% \mathrm{AO}+-+$ stato+-+dottrina+-+.

Ruggeri, Antonio. "Eguaglianza, solidarietà e tecniche decisorie nelle più salienti esperienze della giustizia costituzionale."Rivista dell'Associazione Italiana dei Costituzionalisti, no. 2 (May 2017). https://www.rivistaaic.it/images/rivista/pdf/2_ 2017_Ruggeri.pdf.

Schillaci, Angelo. “Governo dell'economia e gestione dei conflitti nell'Unione Europea: Appunti sul principio di solidarietà." Costituzionalismo.it, no. 1 (March 2017): 27-61. http://www.costituzionalismo.it/download/Costituzionalismo_201701_6o4.pdf.

Tondi delle Mura, Vincenzo. "La solidarietà tra etica ed estetica, Tracce per una ricerca." Rivista dell'Associatione Italiana dei Costitutionalisti, no. oo (July 2010). https://www. rivistaaic.it/images/rivista/pdf/TondidellaMurao1.pdf.

Tubertini, Claudia. "Public Administration in the Light of the New Title V of the Italian Constitution." European Public Law 12, no. 1 (2006): 35-44.

Wiessner, Siegfried. "The Movement Toward Federalism in Italy: A Policy-Oriented Perspective." St. Thomas Law Review 15, no. 2 (Winter 2002): 301-319. 